\title{
Yield losses by Phytonematodes: challenges and opportunities with special reference to Egypt
}

\author{
Mahfouz M. M. Abd-Elgawad
}

Phytopathology Department, National Research Center, El-Tahrir St., Dokki 12622, Giza, Egypt

\section{Abstract}

Plant-parasitic nematodes (PPN) constitute a major constraint to agriculture. Estimates of their crop-loss are important for establishing research, extension, and budget priority. Regulatory policy action, pesticide impact assessment, resource allocation, and program prioritization are usually contingent upon such crop loss data. Recent questionnaire results of important PPN genera and estimates of crop losses in Egypt due to PPN are presented herein. Crop losses due to the nematodes on 80 crops, 15 of which are 'life sustaining', were estimated at L.E. 15.85 (= \$2.30) billion annually based on 2011-2012 Egyptian production figures and prices. Crop loss estimates of vegetables, fruits, and field crops demonstrated staggering figures and therefore nematode problems warrant considerably more effort and support than they are currently receiving. Current challenging nematode issues include reduced number of effective nematicides available and limitation in their use due to environmental issues, increased adoption of intensive agriculture, climate change, occurrence of resistance-breaking PPN pathotypes on economically important crops, and potential introduction of quarantine-nematodes. Therefore, basic and applied nematological research should be more oriented to provide better management of plant-parasitic nematodes in an economically and environmentally beneficial manner.

Key words: Crop production, nematode damage and management, yield loss, Egypt.

\section{Introduction}

Common obstacles hindering perfect estimates of crop losses caused by plant-parasitic nematodes (PPN) have recently been highlighted (Abd-Elgawad and Askary, 2014). Information requirements for crop-loss assessment purposes must include estimates of crop distribution and value, pest distribution and average infestation level, and finally a damage function relating average infestation and crop yield. All these estimates are susceptible to error, and interaction effects among biological components should be considered (Koenning et al., 1999). Yet, studies on the impact of phytonematodes on agriculture are essential because they can let people know how serious nematode problems can be. Such studies are considered the basis for nematode-management options. In Egypt, such information can also develop farmers' awareness of PPN damage and consequently adopt adequate control measures to avoid yield losses and ensure high quality of organic grown 
crops. Strategies solely based on cultural and tillage practices, are frequently not sufficient in controlling the nematodes due to nematode abundance and their broad host spectrum in Egypt (Abd-Elgawad, 2008). Moreover, reliable crop loss estimates are important for establishing research, extension, and budget priority (McSorley et al., 1987). Pest-specific crop-loss information is needed by government agencies; corporations involved with crop protection and production, and university systems for descriptive and predictive purposes (Noling, 1987). Regulatory policy action, pesticide impact assessment, resource allocation, and program prioritization are usually contingent upon crop loss data. Therefore, one should not be discouraged by some cautious tones and limitations in establishing such estimates. Admittedly, it is essential that the full spectrum of crop production limitations is considered appropriately, including the often overlooked phytonematode constraints (Nicol et al., 2011); to maximize agriculture output.

On a global scale, the distribution of nematode species varies greatly while the economic impact of their genera differs (e.g., Evans et al., 1993; Luc et al., 2005). Worldwide economic impact of PPN on agriculture was reported (McSorley et al., 1987; Sasser, 1988; Koenning et al., 1999; Nicol et al., 2011; AbdElgawad and Askary, 2014) but information is scanty on large-scale nematode losses in Egypt. Our goal here is to present the most important PPN genera and their losses in Egypt. Their current challenges and our ability to cope with them are discussed.

\section{Material and Methods}

Assessment of important PPN in Egyptian vegetables, fruits, and field crops. Crops included those in tables (1-3). Ten Ph. D. Egyptian nematologists were asked to rank the five most damaging genera of plant parasitic nematodes occurring in Egypt. Based on the number of first, second, third, fourth and fifth place votes, a weighted index was calculated by giving first place votes a score of 5; second place votes a score of 4 ; third place votes a score of 3; fourth place votes a score of 2; and fifth place votes a score of 1 (Sasser, 1988).

Assessment of their yield losses. Over 70 selected papers, chapters, M. Sc./Ph. D. theses, and books on PPN in Egypt representing different authors, localities, periodicals, years, and crops were thoroughly reviewed to document important phytonematode genera and assess yield losses due to nematodes. Other criteria used to assess such losses comprised Egyptian nematologist and grower interviews, previous reports and visual assessment based on foliage growth (necrotic, chlorotic, stunted, and wilted plants), root symptoms, and educated guess to expert opinions according to Anwar and McKenry (2012). The number of nematologists and growers interviewed was variable and ranged from 4-12 for each crop. Nematologists and growers were selected for their experience on specific crops under all degrees of agrochemical inputs, management intensity and 
productivity. Such interviews included condition of the crop, quantitative and qualitative yield losses based on market value, and life span of the crop. Estimates were reported first as percentage of yield losses then converted to their corresponding monetary losses. The latest Egyptian agricultural statistical tables of 2011-2012 showing areas (in Feddan which equals $4200 \mathrm{~m}^{2}$ ), yield (Ton/Feddan), and production (Ton) for each cultivated crop were obtained from Egyptian Ministry of Agriculture \& Land reclamation (Anonymous, 2012). Based on the Egyptian annual crop production from these data, losses in quantity and value are reproduced after assessment of yield losses. Current challenging PPN issues and their possible solutions were addressed (Abd-Elgawad and Askary, 2014).

\section{Results}

The questionnaire of this study could nominate fourteen genera as the most damaging phytonematodes in Egypt. These genera, with the total weighted votes for each nematode genus received is given in parentheses, were reported to be Meloidogyne (50), Pratylenchus (28), Rotylenchulus (24), Tylenchulus (22), Trichodorus \& Paratrichodorus (5), Heterodera (5), Tylenchorhynchus (4), Helicotylenchus (3), Hoplolaimus (2), Aphelenchoides (2), Hirschmanniella (2), Ditylenchus (1), Xiphinema (1), and Longidorus (1).

Annual losses due to nematodes on 37 vegetables (Table 1), 25 field crops (Table 2), and 18 tree fruits (Table 3) were estimated at L.E. 5.12, 8.05, and 2.68 billion, respectively, based on 2011-2012 Egyptian production figures and prices on wholesaling basis; not retail. Average estimates of their corresponding annual yield losses are $11.35,8.76$, and $10.28 \%$. So, crop losses due to nematodes on all the 80 Egyptian crops, 15 of which are life sustaining crops according to Wittwer (1981), were estimated at L.E.15.85 (= \$2.3) billion annually. The life sustaining crops, include banana, barley, chickpea, corn, field bean, peanut, pigeon pea, potato, rice, sorghum, soybean, sugar beet, sugar cane, sweet potato, and wheat, that stand between man and starvation, suffered $9 \%$ as an average yield loss. Damage estimates for non-food plants including ornamentals, turf, and forest trees were not included. Therefore, the total nematode damage may exceed these figures. Also, the increase in commodity prices since 2011 may inflate this estimate further. In addition, the temporal change in value of the dollar relative to Egyptian currency should be considered. Eventually, estimated overall average annual loss on the Egyptian major vegetable, field, and fruit crops due to damage by PPN, equaled $10.13 \%$. is less than that $(12.3 \%)$ of previous average estimate for world's major crops (Sasser and Freckman, 1987). This is probably due to significant contributions made to nematology during the past years. Yet, the above-mentioned estimates demonstrated staggering figures and therefore nematode problems warrant considerably more effort and support than they are currently receiving. 
Table (1): Summary of estimated annual yield losses in vegetables due to damage by plant parasitic nematodes in Egypt*.

\begin{tabular}{|c|c|c|c|c|c|}
\hline Varieties & $\begin{array}{c}\text { Loss } \\
(\%)\end{array}$ & $\begin{array}{l}\text { Actual production } \\
\text { (metric tons) }\end{array}$ & $\begin{array}{c}\text { Price } \\
\text { (L.E./ton) }\end{array}$ & $\begin{array}{c}\text { Actual loss } \\
\text { (metric tons) }\end{array}$ & $\begin{array}{c}\text { Loss } \\
\text { (Million L.E.) }\end{array}$ \\
\hline Tomato & $12 \%$ & 8571050 & 1500 & 1168779.5 & 1753.17 \\
\hline Squash & $20 \%$ & 559598 & 1000 & 139899.5 & 139.9 \\
\hline Green bean & $7 \%$ & 251279 & 3000 & 18913.44 & 56.74 \\
\hline Dry bean & $7 \%$ & 69486 & 5000 & 5230.13 & 26.15 \\
\hline Green cowpea & $10 \%$ & 24277 & 3000 & 2697.44 & 8.09 \\
\hline Dry cowpea & $10 \%$ & 12950 & 5000 & 1438.89 & 7.19 \\
\hline Green pea & $12 \%$ & 180631 & 4000 & 24631.5 & 98.53 \\
\hline Dry pea & $12 \%$ & 124 & 6000 & 16.91 & 0.10 \\
\hline Cabbage & $9 \%$ & 638227 & 500 & 63121.35 & 31.56 \\
\hline Cauliflower & $5 \%$ & 171088 & 500 & 9004.63 & 4.50 \\
\hline Eggplant & $20 \%$ & 1193642 & 1000 & 298410.5 & 298.41 \\
\hline Pepper & $22 \%$ & 650554 & 2000 & 183489.59 & 366.98 \\
\hline Okra & $13 \%$ & 97108 & 3500 & 14510.39 & 50.79 \\
\hline Jew's mallow & $6 \%$ & 80316 & 1000 & 5126.55 & 5.13 \\
\hline Spinach & $10 \%$ & 39413 & 2500 & 4379.22 & 10.95 \\
\hline Mallow & $8 \%$ & 2161 & 1000 & 187.91 & 0.19 \\
\hline Artichokes & $10 \%$ & 387704 & 1500 & 43078.22 & 64.62 \\
\hline Taro & $6 \%$ & 118759 & 2000 & 7580.36 & 15.16 \\
\hline Radish & $10 \%$ & 12000 & 800 & 1333.33 & 1.07 \\
\hline Turnip & $8 \%$ & 32779 & 500 & 2850.35 & 1.43 \\
\hline Lettuce & $12 \%$ & 93661 & 2000 & 12771.96 & 25.54 \\
\hline Carrot & $13 \%$ & 179291 & 2000 & 26790.61 & 53.58 \\
\hline Parsley & $8 \%$ & 88487 & 1000 & 7694.52 & 7.69 \\
\hline Arugula & $7 \%$ & 52281 & 1000 & 3935.13 & 3.94 \\
\hline Egyptian leek & $10 \%$ & 31223 & 1000 & 34692.22 & 34.69 \\
\hline Sweet Potato & $7 \%$ & 319427 & 750 & 24042.89 & 18.03 \\
\hline Strawberry & $12 \%$ & 242297 & 2000 & 33040.5 & 66.08 \\
\hline Beet & $10 \%$ & 3518 & 2000 & 390.89 & 0.78 \\
\hline Pumpkin & $17 \%$ & 1256 & 1200 & 257.25 & 308.7 \\
\hline Watermelon & $14 \%$ & 1874710 & 1200 & 305185.35 & 366.22 \\
\hline Cucumber & $15 \%$ & 587612 & 1500 & 103696.24 & 155.54 \\
\hline Armenian cucumber & $15 \%$ & 50568 & 1400 & 8923.76 & 12.49 \\
\hline Cantaloupe & $15 \%$ & 854204 & 1500 & 150741.88 & 226.11 \\
\hline Melon & $15 \%$ & 89927 & 1400 & 15869.47 & 22.22 \\
\hline Shahad & $15 \%$ & 62716 & 1600 & 11067.53 & 17.71 \\
\hline Potato & $8 \%$ & 4758040 & 2000 & 413742.61 & 827.49 \\
\hline water melon pulp seeds & $10 \%$ & 67274 & 4500 & 7474.89 & 33.64 \\
\hline
\end{tabular}

*Based on 2011-2012 total Egyptian production figures and prices on wholesaling basis; not retail. 
Table (2): Summary of estimated annual yield losses in field crops due to damage by plant parasitic nematodes in Egypt*.

\begin{tabular}{|c|c|c|c|c|c|}
\hline Varieties & $\begin{array}{l}\text { Loss } \\
(\%)\end{array}$ & $\begin{array}{l}\text { Actual production } \\
\text { (metric tons) }\end{array}$ & $\begin{array}{c}\text { Price } \\
\text { (L.E./ton) }\end{array}$ & $\begin{array}{c}\text { Actual loss } \\
\text { (metric tons) }\end{array}$ & $\begin{array}{c}\text { Loss } \\
\text { (Million L.E.) }\end{array}$ \\
\hline Corn & $10 \%$ & 7205541.6 & 2750 & 800615.73 & 2201.69 \\
\hline Rice & $9 \%$ & 5896577 & 2000 & 583177.95 & 1166.36 \\
\hline Sorghum & $4 \%$ & 750894.34 & 2500 & 31287.26 & 78.22 \\
\hline Soybean & $8 \%$ & 25939 & 3500 & 2255.57 & 7.89 \\
\hline Peanut & $20 \%$ & 205393.13 & 8000 & 51348.28 & 410.79 \\
\hline Sesame & $12 \%$ & 31270.92 & 6000 & 4264.22 & 25.59 \\
\hline Common Sunflower & $20 \%$ & 19948 & 2000 & 4987 & 9.97 \\
\hline Sunflower & $20 \%$ & 19987 & 1700 & 4996.75 & 8.49 \\
\hline Onion & $5 \%$ & 126595 & 1500 & 6662.89 & 9.99 \\
\hline Wheat & $7 \%$ & 8795483.1 & 2800 & 662025.61 & 1853.67 \\
\hline Barley & $2 \%$ & 108495.24 & 2000 & 2214.19 & 4.43 \\
\hline Faba bean (dry) & $7 \%$ & 140712.88 & 6000 & 10591.29 & 63.55 \\
\hline Faba bean (green) & $7 \%$ & 52430 & 2500 & 3946.34 & 9.87 \\
\hline Lentil & $10 \%$ & 718.08 & 8000 & 79.79 & 0.64 \\
\hline Chickpea & $5 \%$ & 3106.2 & 8000 & 163.48 & 1.31 \\
\hline Lupine & $5 \%$ & 1551.15 & 6000 & 81.64 & 0.49 \\
\hline Fenugreek & $3 \%$ & 5281.62 & 8000 & 163.35 & 1.31 \\
\hline Sugar beet & $12 \%$ & 9126058 & 350 & 1244462.5 & 435.56 \\
\hline Sugar cane & $14 \%$ & 13475000 & 300 & 2193604.7 & 658.08 \\
\hline Berseem clover (cut) & $9 \%$ & 39855255 & 200 & 3941728.5 & 788.35 \\
\hline Berseem clover (seed) & $9 \%$ & 31393.25 & 3000 & 3104.83 & 9.31 \\
\hline Flax (fiber) & $7 \%$ & 51742 & 10000 & 3894.56 & 38.94 \\
\hline Flax (seed) & $7 \%$ & 5724.484 & 8000 & 430.88 & 3.45 \\
\hline Garlic & $2 \%$ & 309155 & 10000 & 6309.29 & 63.09 \\
\hline Cotton & $5 \%$ & 635000 & 6000 & 33421.05 & 200.53 \\
\hline
\end{tabular}

*Based on 2011-2012 total Egyptian production figures and prices on wholesaling basis; not retail. 
Table (3): Summary of estimated annual yield losses in production of fruits due to damage by plant parasitic nematodes in Egypt*.

\begin{tabular}{lccccc}
\hline \multicolumn{1}{c}{ Varieties } & $\begin{array}{c}\text { Loss } \\
(\%)\end{array}$ & $\begin{array}{c}\text { Actual production } \\
\text { (metric tons) }\end{array}$ & $\begin{array}{c}\text { Price } \\
\text { (L.E./ton) }\end{array}$ & $\begin{array}{c}\text { Actual loss } \\
\text { (metric tons) }\end{array}$ & $\begin{array}{c}\text { Loss } \\
\text { (Million L.E.) }\end{array}$ \\
\hline Oranges & $10 \%$ & 2577720 & 1000 & 286413.33 & 286.41 \\
Citrus & $10 \%$ & 1152965 & 1000 & 128107.22 & 128.11 \\
Grape & $15 \%$ & 1320801 & 1000 & 233082.52 & 233.08 \\
Mango & $5 \%$ & 598084 & 5000 & 31478.11 & 157.39 \\
Banana & $17 \%$ & 1054243 & 4000 & 215929.29 & 863.72 \\
Fig & $10 \%$ & 165483 & 4000 & 18387 & 73.55 \\
Prickly Pear & $7 \%$ & 27290 & 1000 & 2054.09 & 2.05 \\
Guava & $8 \%$ & 339354 & 1500 & 29509.04 & 44.26 \\
Pomegranate & $10 \%$ & 64574 & 2500 & 7174.89 & 17.94 \\
Apricot & $8 \%$ & 96643 & 8000 & 8403.74 & 67.23 \\
Pear & $7 \%$ & 48817 & 8000 & 3674.4 & 29.4 \\
Apple & $12 \%$ & 455817 & 3000 & 62156.86 & 186.5 \\
Peach & $20 \%$ & 332487 & 1500 & 83121.75 & 124.68 \\
Plum & $6 \%$ & 12666 & 7500 & 808.47 & 6.06 \\
Olive & $10 \%$ & 459650 & 2500 & 51072 & 127.68 \\
Almond & $10 \%$ & 18222 & 20000 & 2024.67 & 40.49 \\
Papaya & $12 \%$ & 6000 & 2000 & 818.18 & 1.64 \\
Date-palm & 1113270 & 3000 & 96806.09 & 290.42 \\
\hline Based & $8 \%$ & & & & \\
\hline
\end{tabular}

*Based on 2011-2012 total Egyptian production figures and prices on wholesaling basis; not retail.

\section{Discussion}

The present questionnaire addressed 14 phytonematode genera in Egypt as the most economically important nematodes. These genera comprise 162 worldwide species which fulfilled one or more of the criteria to be considered to present a phytosanitary risk according to Singh et al. (2013). Other genera found in Egypt; include Aphelenchus, Anguina, Merlinius, Paratylenchus, Dolichodorus, Mesocriconema and Fergusobia (Ibrahim, 2007; Kella and Bekhiet, 2011); did not get a vote. Although PPN of economic importance can be grouped into relatively restricted specialized groups, others previously viewed as benign or non-damaging, are becoming pests as cropping patterns change (Nicol, 2002; Nicol et al., 2011), while new species are continually being described. A comprehensive list of main 
hosts and yield loss estimates are recently provided (Singh et al., 2013) with an extensive bibliography for each of 250 phytonematode species, from 43 genera including those voted for in the present questionnaire, considered to present a phytosanitary risk.

Compared to other worldwide survey (Sasser and Freckman, 1987), Meloidogyne and Pratylenchus are still first but Rotylenchulus and Tylenchulus are relatively high on the current list. In Europe, however, Heterodera (161), Globodera (156), Meloidogyne (100), Ditylenchus (93), Pratylenchus (88), Aphelenchoides (26), Xiphinema (26), Longidorus (17) and Tylenchulus (8) were recorded to be most damaging to plants (Sasser, 1988). In a recent worldwide questionnaire, Jones et al. (2013) reported that the top 10 PPN genera/species were composed of: 1) Meloidogyne; 2) Heterodera and Globodera; 3) Pratylenchus; 4) Radopholus similis; 5) Ditylenchus dipsaci; 6) Bursaphelenchus xylophilus; 7) Rotylenchulus reniformis; 8) Xiphinema index; 9) Nacobbus aberrans; and 10) Aphelenchoides besseyi. Their order, based on scientific and economic importance, varies from those listed in the current survey probably because of difference in regions, climate, and prevailing crops. Yet, Jones et al. (2013) bestowed honorable mention to some important nematodes missed out in their questionnaire. They included Helicotylenchus spp. (Subbotin et al., 2011) and the ectoparasitic Trichodorus spp., the vector of Tobacco rattle virus (Decraemer and Geraert, 2006) which are recognized herein with low poll ratings.

The overall average annual loss on the 80 Egyptian crops (Tables 1-3) due to damage by PPN is less than that of previous average estimate (Sasser and Freckman, 1987) for world's major crops (i.e. 10.13\% vs. 12.3\%). Although Egypt is a developing country, the losses may probably be due to significant contributions made to nematology during the past years in general. Yet, the above-mentioned estimates demonstrated relatively high losses and therefore nematode problems warrant considerably more effort and support than they are currently receiving.

Staggering were the estimates as reported by Sasser and Freckman (1987) or herein (Tables 1-3) for the high nematode-losses, further unexpected bad effects have been occurring, in a way that may aggravate such losses in Egypt. Such factors include reduced number of effective nematicides available and limitation in their use due to environmental issues, increased adoption of intensive agriculture, climate change, occurrence of resistance-breaking PPN pathotypes on economically important crops, and potential introduction of quarantine-nematodes especially with plant propagation materials. Similar factors may be considered worldwide (Abd- Elgawad and Askary, 2014). Therefore, research and management of plant-parasitic nematodes should be carried out in an economically and environmentally beneficial manner; briefly as follows: 


\section{Safe and Tactful use of applicable nematicides}

Because most phytoparasitic nematodes spend their lives confined to the soil or within plant roots, delivery of a chemical nematicide to the immediate surroundings of a nematode is difficult. The outer surface of nematodes is a poor biochemical target and is impermeable to many organic molecules. Delivery of a toxic compound by an oral route is nearly impossible because most phytoparasitic species ingest material only when feeding on plant roots. Consequently, synthetic nematicides have tended to be broad-spectrum toxicants possessing high volatility or other properties promoting migration through the soil (Chitwood, 2003). Therefore, several chemical nematicides have been withdrawn from the market due to their serious threats to natural biological control processes, wildlife, groundwater contamination, resource depletion, and human health and safety. Furthermore, the resulting record of less-than-perfect environmental or human health safety has resulted in the widespread deregistration of several agronomically important chemical nematicides (e.g., ethylene dibromide and dibromochloropropane). More recently, the most important remaining fumigant nematicide, methyl bromide, has been banned because of concerns about atmospheric ozone depletion as well. In addition to their health hazards, many chemical pesticides are expensive, or have been withdrawn from use which has led to increased interest in organic methods for crop and pest management for many crop production systems. In other words, growing dissatisfaction with such chemicals required environmentally friendly pathogen control approaches. The future of nematicides for the control of nematodes will depend on the formulation of new compounds that are effective and environmentally safe. The development of other application technology, e.g. treatment by seed coating or chemicals applied through chemigation as well as development of systemic nematicides is urgently needed.

\section{Intensive agriculture system}

This system uses high levels of complementary inputs, e.g. fertilizers and pesticides to achieve maximum yields at the lowest possible cost from the same cultivated area. Indeed, the list of negative effects of intensive farming seems to be getting longer: soil degradation, salination of irrigated areas, over-extraction and pollution of groundwater, resistance to pesticides including nematicides, erosion of biodiversity, etc. (http:// www.euractiv.com/ cap/ intensive-farming-ecologicallys-linksdossier -506029). In Florida, intensive citriculture system suppressed entomopathogenic nematodes and consequently had the potential to exacerbate herbivory by insect pests (Campos-Herrera et al., 2013).

\section{Climate change}

The most likely consequences of climate change are shifts in the geographical distribution of plant host and pathogen and altered crop losses, caused in part by changes in the efficacy of control strategies (Coakley et al., 
1999). Such a change does not exclude the threat of the emergence of new pests, including nematodes (Nicol et al., 2011). Carter et al. (1996) predicted the increase of the root-knot nematodes (RKNs) as climate change because of additional pathogen generations per year in a warmer climate. This is especially important since most nematode life processes have thermic optima that determine the ideal geographic ranges of nematodes (Luc et al., 2005). Boag et al. (1991) used data from soil samples collected during the European PPN Survey to assess the possible impacts of climate warming on the geographical range of virus-vector nematodes. Initial analyses of nematode presence-absence data suggested a close association between mean July soil temperature and nematode distribution. Based on this result, the authors predicted that climate change could result in increased nematode and virus problems in northern Europe; they estimated that a $10{ }^{\circ} \mathrm{C}$ warming would allow the nematode species in study to migrate northward by 160 to $200 \mathrm{~km}$ (Neilson and Boag, 1996). Although nematodes migrate very slowly, humans are credited with efficiently disseminating them. Nematode spread into new regions could put a wide range of crops at risk; additionally, introduction of new crops into a region could also expose them to infestation by nematode species already present. Changes in precipitation could influence nematode distribution on a large scale, although previous findings had suggested that soil moisture would not affect nematode distribution in most agricultural soils in northern Europe (Boag et al., 1991; Neilson and Boag, 1996; Coakley et al., 1999). Yet, in an alternative example, the rice root knot nematode, Meloidogyne graminicola, can be maintained under damaging levels through good water management. However, with reduced availability of water following climatic changes and/or competition for urban use, reduced quality of water management, or the introduction of water saving mechanisms such as direct wet seeding is favoring the development of high populations of $M$. graminicola, drastically raising its damage. Also, Radopholus similis occurs only below $\sim 1,400 \mathrm{~m}$ altitude in the East African Highlands where it is a principal pest of banana and plantain, a regional key starch staple for over 20 million people. A small raise in temperature would result in $R$. similis, which is coldsensitive, infecting millions more bananas grown at higher altitudes (De Waele and Elsen 2007, as in Nicol et al., 2011). So, programs to prevent nematode spread into new regions should be initiated and precisely applied (e.g. Sikora et al., 2005; Abd-Elgawad and McSorley, 2009).

\section{Lag in nematode-genetic manipulation}

Nematode control through genetic resistance is still insufficient although an extensive list of major annual and perennial crops carrying resistance to root-knot, cyst, and other PPN was recently reported (Molinari, 2011). Plant cultivars with high-standard agricultural traits of tomato, tobacco, cotton, peanut resistant to Meloidogyne spp., of potato resistant to Globodera spp., and soybean resistant to Heterodera spp. are commercially available for growers (Starr and Roberts, 2004). 
While some crops benefit from resistance, many lack identified resistant germplasm (McCarter, 2008). Furthermore, resistance breaking through selection of virulent nematode populations (e.g. soy parasites) or selection for non-susceptible species (e.g. potato parasites) can occur, lessening the trait's value (Starr et al., 2002). Root-knot and cyst nematodes, and perhaps other species, have the capacity to develop new strains and races when cultivars resistant to these forms are planted too frequently (Sasser and Freckman, 1987). For example, five of nine populations of Meloidogyne spp. from Greece, identified as $M$. javanica (4 populations) and Meloidogyne incognita (one population) using either isozyme phenotypes or the sequence characterized amplified region-polymerase chain reaction (SCAR-PCR) technique, were virulent against the $M i$ resistance gene as assayed by pot experiments in controlled conditions. These populations could reproduce on tomato cultivars containing that gene (Tzortzakakis et al., 2005). Also, hypersensitive resistance $(\mathrm{HR})$ to the common root-knot nematode species was clearly observed in infested roots of tetraploid potato clones that have been tested previously by UMR APBV-Potato team (Berthou et al., 2003 and Kouassi et al., 2005), but such HR observations were not so distinct in the histopathological changes induced by Egyptian $M$. incognita population probably because the Egyptian nematode population is more virulent (Eddaoudi et al., 1997) and/or other stressing environmental factors have accounted for such variations since some nematodesecond stage juveniles $\left(\mathrm{J}_{2}\right)$ were found active even after 10 days of inoculation (Abd-Elgawad et al., 2012). Moreover, despite the above-mentioned progress in molecular nematology, no transgenic approaches to resistance have reached commercialization and nematode control lags behind transgenic control of insects, viruses, and fungi. This lack of improved technology reaching the grower has been detrimental to nematology as a discipline and has coincided with static-to-declining numbers of trained applied nematologists, particularly in the United States (McCarter, 2008). On the other hand, genetic basis of resistance and virulence along with interactions leading to incompatible/compatible responses of the plants to nematodes and the role of some important hormones in plants and genetic variability of nematode populations were recently reviewed (Molinari, 2012). Racenon-specific (horizontal) resistance should be targeted as opposed to gene-for-gene recognition system including HR (Keane, 2012).

\section{Quarantine problems}

Quarantine and certification programs are important in limiting the spread of PPN but the programs cause indirect costs in addition to direct loss. For example, $M$. chitwoodi and $M$. fallax are increasingly regulated as they can be spread through seed potatoes and potato tubers infested by PCN from Europe. As is widely accepted, quarantine cannot be feasibly carried out to all units of transferable plants, pots, soil and cuttings. Comprehensive precautions should be implemented for complete protection against a species as yet not found in a country (Salama and 
Abd-Elgawad, 2003). Complete certainty of pest absence can be assured only if every unit in the lot is inspected. Unfortunately, testing every unit is sometimes neither economical nor practical. So, it is usually necessary to sample a portion of the units in the lot, and to accept or reject the entire lot based on the results. The inspector must assume some risk and set limits defining freedom from infestation, e.g., less than $1 \%$ of units infested, or less than 5 units infested, since it is a choice between objectives and available fund. Also, effect of sample size on the probability of detecting PPN species in a polyspecific nematode population and comparison of observed with expected rates of failure to detect this nematode by soil sampling in several locations were reported (Abd-Elgawad and McSorley, 2009).

Despite great efforts exerted on quarantine, striking examples of faulty quarantine regulations have led to the spontaneous introduction of nematode pests. B. xylophilus, associated with pine wilt disease but depends on bark beetles (Monochamus spp.) to spread from tree to tree, is native to North America and is thought to have been carried to Japan at the beginning of the twentieth century on timber exports (Nicol et al., 2011). In Japan, it is causing massive mortality of native pine trees. In 1999, B. xylophilus was found in Europe for the first time, in Portugal. Quarantine nematologists were already researching the identity of this species in order to be able to distinguish it from the many species of Bursaphelenchus that inhabit wood. Unfortunately, there is a variation in characters between species in the Bursaphelenchus group, which makes morphological identification particularly difficult, so biomolecular tools, e.g. sequencing, speciesspecific primers and probes, are highly recommended (OEPP/EPPO, 2009a). Likewise, molecular and reliable protocols for quarantine species such as $G$. rostochiensis and G. pallida (OEPP/EPPO, 2009b), M. chitwoodi, M. fallax (OEPP/EPPO, 2009c), and Xiphinema americanum sensu lato (OEPP/EPPO, 2009d) were established while others are in progress. Generally, the cost of such protocols might vary from one country to another. For example, the double labeled TaqMan probe type might cost approximately $\$ 200$ in USA, \$600 in Brazil, and $\$ 450$ in Spain, in the same company, and also, it is possible to have different price/quantities and qualities depending on the company selected; it is conceivable that, hence, the rest of the reagents used for these protocols (master mix, plate, film ...etc) might change as well, although the function and use of these products are equivalent. Admittedly, in the countries where such technologies are currently under development and equipment not certainly easily available, as in Egypt, an extra implementation, with more costs, will be required for performing the same protocols. A comparative of these costs by countries or continents may give a very good idea of which are the potential and the limitations in including these molecular analysis. Moreover, such analyses require materials that sometimes are not considered in the initial budget, and at the end it significantly increases the final cost. It is important to highlight again that costs may also differ with other companies selected for the reagents or material, such as Applied Biosystem, Qiagen (http://www.qiagen.com/) 
and IDT Technologies (http://eu.idtdna.com). Yet, at any rate, strict conduction of such protocols will prevent the introduction and spread of quarantine species in new areas/states; thereby saving millions of dollars in annual crop losses (Handoo et al., 2013). Holgado and Magnusson (2012) addressed the current status and perspectives of quarantine nematodes in the light of European legislation. They stressed the need to have actualized statistic data to provide information on problems emanating from particular sources, areas or suppliers, to determine priorities for targeting inspections and monitoring consignments with high risk to the agricultural industry in their countries and to perform a Pest Risk Analysis (PRA). Such data are urgently needed for decision-makers in Egypt too.

\section{Confusion in identification of some PPN species and races}

The names of regulated PPN need to be as firmly established as possible. This requires awareness of the fact that some species might be subject to many taxonomic changes, and that there may exist many synonyms in the legislation of some countries; this needs to be recognized to avoid confusion and allow for the correct phytosanitary action to be taken. Examples of this controversy are Radopholus citrophilus and $R$. similis, which are both listed in European legislation. $R$. similis was thought to consist of different pathotypes but Huettel et al. (1984) concluded that the banana race and the citrus race were two distinct species; the name $R$. similis was restricted to the banana race, and the citrus race was described as $R$. citrophilus. Later, Kaplan et al., (1997) synonymized $R$. citrophilus with $R$. similis; Valette et al., (1998) proposed $R$. citrophilus as a junior synonym of $R$. similis, although Siddiqi (2000) proposed it as a subspecies of $R$. similis, and Elbadri et al. (2002), using molecular techniques, demonstrated marked intraspecific variation in various isolates of $R$. similis. This continuing taxonomic uncertainty has caused confusion for quarantine officers and specialists involved in PRA work, due to the uncertainty on the actual host lists of $R$. similis (Holgado and Magnusson, 2012). More recently, $M$. enterolobii and $M$. mayaguensis were considered separate species, but their recent synonymization meant that when distribution, host range and other information published under both names were consolidated, the apparent risk increased substantially. Therefore, information published under species synonyms also needs to be considered when assessing phytosanitary importance (Singh et al., 2013). On the other hand, splitting of a species (e.g. the new species Ditylenchus gigas and D. weischeri, previously considered as part of $D$. dipsaci species complex (Chizhov et al., 2010; Vovlas et al., 2011) demonstrated that the distributions and phytosanitary importance of closely related or cryptic species and races could be assessed more precisely with more specific identification methods. Admittedly, uncertainties concerning the validity of nematode species will lead to practical problems related to quarantine measures and nematode management as well as highlight the importance of research into taxonomy and specific identification methods. 


\section{Discrepancy in nematode technological progress among countries}

Addressing recent nematological issues will pose additional challenges to tropical and subtropical nematology since there has been discrepancy in nematode technological progress between the North and the South countries (Luc et al., 2005). Moreover, the increased application of molecular diagnostics may widen the knowledge gap between nematologists working in developed and developing countries. The study of interactions between nematodes and other pathogens in disease complexes provide opportunities for multidisciplinary research with scientists from other disciplines but remain fairly underexploited. Contrary to developed countries, difficulties in recognizing emerging nematode threats in developing countries, like Egypt, prevent the timely implementation of management strategies, thus increasing yield losses. For example, in USA, the immediate implementation of a federal quarantine on the pale cyst nematode, Globodera pallida, as a serious pest helped prevent the spread of this species in the United States; thereby saving millions of dollars in annual crop losses (Handoo et al., 2013). This is especially important since over-population occurs predominantly in developing, mostly tropical and subtropical, countries where the majority of hungry people live.

\section{Inaction or shift in PPN management}

Even in the developed countries, forgotten nematode problems can reappear all of a sudden as rotation sequences are altered or new cultivars introduced, as has been seen with new outbreaks of PCN and sugarbeet stem nematode $D$. dipsaci (Luc et al., 2005). A problem new to a particular country could arise through the introduction and subsequent spread of a known nematode parasite from another temperate country. It is, therefore, the case in temperate countries that surveys are designed to determine the distribution of known nematodes causing known damage. In contrast, in the subtropical and tropical areas, new problems are being, and have yet to be, discovered involving new nematode species and even genera, or species not recorded as harmful to a crop. Examples are the 'legume Voltaic chlorosis' of leguminous crops, discovered in Burkina Faso, associated with a new species, Aphasmatylenchus straturatus, and a genus not previously known to be a harmful parasite (Germani and Luc, 1982). In Egypt, A. besseyi causing white tip leaf disease on rice was detected (Amin, 2001) and most recently aerial shoot galls on camphor trees induced by the plant parasitic nematode, Fergusobia spp., and the dipterous insect, Fergusonina spp. were reported in several Egyptian governorates during winter, spring, summer and autumn seasons (Kella and Bekhiet, 2011).

\section{Lack of economically-oriented PPN research}

We believe that more economically-oriented research work should be followed. McCarter (2008) proved this case by figures. Nearly half of the total (48\%) 
yield loss caused by nematodes derives from just two crops, rice (Bridge et al., 2005) and maize (McDonald and Nicol, 2005), which dominate because of their overall predominance in world agriculture. Twenty-eight percent of the total loss derives from rice in China and maize in the US alone. Despite the impact of rice and maize on the estimated total yield loss, few molecular nematologists focus their research on these crops and the associated nematode pathogens. While 29 species of nematodes parasitize rice, studies of disease distribution and yield loss in rice have been limited (Bridge et al., 2005), and international agricultural research centers have employed a minimal number of nematologists (Luc et al., 2005). Similar situations might be found in Egypt if not even worse. Therefore, basic and applied nematological research should be more oriented in Egypt to improve management tactics and strategy of phytonematodes in a more economically and environmentally useful array.

\section{Acknowledgements}

I would like to thank Tarique $\mathrm{H}$. Askary who accepted to comment, revise, and expand on this questionnaire and related text to become in the form of a possible book chapter authored by us both in the future. Thanks are extended to Drs. Robert McSorley, Mohamed F.M. Eissa, Hoda H. Amin, Hamida A. Osman, M. Youssef, A. Korayem, Wafaa A. El-Nagdi, Asmahan M. Shawkey, Zafar Handoo, Raquel Campos-Herrera, Mostafa Hammam, Violeta Oro, and Moawad Mohamed, for the information provided and/or help in preparing the manuscript. This research was supported in part by In-House project No. 10120604 Entitled "Integrated management of nematode pests and pre- and post-harvest diseases of economically important crops" and USA-Egypt fund project No. 338.

\section{References}

Abd-Elgawad, M.M.M. (2008). The current status of phytonematode management in Egypt with special reference to applicable nematicides. Egyptian Journal of Agronematology 6: 33-46.

Abd-Elgawad, M.M.M. and McSorley, R. (2009). Movement of citrus nematodeinfested material onto virgin land: detection, current status and solutions with cost-benefit analysis for Egypt. Egyptian Journal of Agronematology 7(1):35-48.

Abd-Elgawad, M.M.M., Kerlan, M., Molinari, S., Abd-El-Kareem, F., Kabeil, S.S.A., Mohamed, M.M., and El-Nagdi, W.A. (2012). Histopathological changes and enzymatic activities induced by Meloidogyne incognita on resistant and susceptible potato. eSci Journal of Plant Pathology 1: 62-72.

Abd-Elgawad, M.M.M. and Askary, T.H. (2014). Impact of phytonematodes on agriculture economy. In: Askary, T.H. and Martinelli, P.R.P. (eds), Biocontrol Agents of Phytonematodes. CAB International, Wallingford, UK: In press. 
Amin, A.W. (2001). First record of Aphelenchoides besseyi Christie, 1942 (Nematoda: Aphelenchoididae) in Egypt causing white tip leaf disease on rice. Opuscula Zoologica (Budapest) 33: 3-6.

Anonymous (2012). Area, productivity and production of Vegetable Crops for total seasons of year 2012. Egyptian Economic Affairs Sector, Ministry of Agriculture and Land Reclamation, Giza, Egypt (in Arabic).

Anwar, S.A. and McKenry, M.V. (2012). Incidence and population density of plantparasitic nematodes infecting vegetable crops and associated yield losses in Punjab, Pakistan. Pakistan Journal of Zoology 44: 327-333.

Berthou, F., Kouassi, A., Bossis, M., Dante, J.P., Eddaoudi, M., Ferji, Z., Pelle, R., Taghzouti, M., Ellisseche, D., Mugniery, D. (2003). Enhancing the resistance of the potato to tropical and mediterranean root-knot nematodes by using ex-Solanum sparsipilum germplasm. Euphytica 132: 57-65.

Boag, B., Crawford, J.W. and Neilson, R. (1991). The effect of potential climatic changes on the geographical distribution of the plant-parasitic nematodes Xiphinema and Longidorus in Europe. Nematologica 37: 312-23.

Bridge, J., Plowright, R.A., Peng, D. (2005). Nematode parasites of rice. In: Luc, M., Sikora, R.A., and Bridge, J. (Eds). Plant Parasitic Nematodes in Subtropical and Tropical Agriculture, 2nd edn. CAB International, Wallingford, UK, pp. 87-130.

Campos-Herrera, R., Pathak, E., El-Borai, F.E., Schumann, A., Abd-Elgawad, M.M.M., and Duncan, L.W. (2013). New citriculture system suppresses native and augmented entomopathogenic nematodes. Biological Control 66: 183-194.

Carter, T.R., Nurro, M. and Torkko, S. (1996). Global climate change and agriculture in the North. Agricultural and Food Science in Finland 5: 223385.

Chitwood, D.J. (2003). Nematicides. In: Plimmer, J.R. (Ed). Encyclopedia of Agrochemicals, Vol. 3. John Wiley \& Sons, New York, USA, pp.1104-1115.

Chizhov, V.N., Borisov, B.A. and Subbotin, S.A. (2010). A new stem nematode, Ditylenchus weischeri sp. n. (Nematoda: Tylenchida), a parasite of Cirsium arvense (L.) Scop. in the Central Region of the Non-Chernozem Zone of Russia. Russian Journal of Nematology 18: 95-102.

Coakley, S.M., Scherm, H., Chakraborty, S. (1999). Climate change and plant disease Management. Annual Review of phytopathology 37: 399-426.

Decraemer, W. and Geraert, E. (2006). Ectoparasitic nematodes. In: Perry, R.N. and Moens, M. (eds). Plant Nematology. CAB International, Wallingford, UK, pp. 153-184. 
Decraemer, W. and Hunt, D.J. (2006). Structure and classification. In: Perry, R.N. and Moens, M. (eds). Plant Nematology. CAB International, UK, Wallingford, Oxfordshire, pp. 3-32.

De Waele, D. and Elsen, A. (2007). Challenges in Tropical Plant Nematology. Annual Review of Phytopathology 45: 457-485.

Eddaoudi, M., Ammati, M. and Rammah, A. (1997). Identification of resistance breaking populations of Meloidogyne on tomatoes and their effects on a new source of resistance. Fundamental and Applied Nematology 20: 285289.

Elbadri, G.A.A., De Ley, P., Waeyenberge, L., Vierstraete, A., Moens, M. and Vanfleteren, J. (2002). Intraspecific variation in Radopholus similis isolates assessed with restriction fragment length polymorphism and DNA sequencing of the internal transcribed spacer region of the ribosomal RNA cistron. International Journal of Parasitology 32(2): 199-205.

Evans, K., Trudgill, D.J. and Webster, J.M. (1993). Plant Parasitic Nematodes in Temperate Agriculture. CAB International, Wallingford, UK.

Germani, G. and Luc, M. (1982). Etudes sur la chlorose voltaïque des légumineuses due au Nématode Aphasmatylenchus straturatus Germani. 1 \& 2. Revue de Nématologie 5, 139-146 and 161-168.

Handoo, Z.A., Mowery, J.D. and Chitwood, D.J. (2013). The history of the USDA nematode collection and its database: valuable resources for taxonomic research and identification. Proceedings of the $10^{\text {th }}$ Int. Nematological Symposium, Russian Society of Nematologists, Golitsyno - Bolshie Vyazemy/ Moscow, 1-5 July, 2013, pp. 110-113.

Holgado, R. and Magnusson, C. (2012). Quarantine Nematodes-European Legislation: current status and perspectives. http://www.izbis.com/ aktuelnosti2012/ nematoda/Nematode1.pdf

Huettel, R.N., Dickson, D.W. and Kaplan, D.T. (1984). Radopholus citrophilus n. sp. (Nematoda), a sibling species of Radopholus similis. Proceedings of the Helminthological Society of Washington 51: 32-35.

Ibrahim, I.K.A. (2007) Diseases and pests of field crops and the control methods in Egypt (In Arabic). Monshaat Al-Maaref Publisher, Al-Raml Station, Alexandria, Egypt. P. 320.

Jones, J.T., Haegeman, A., Danchin, E.G.J., Gaur, H.S., Helder, J., Jones, M.G.K., Kikuchi, T., Manzanilla-López, R., Palomares-Rius, J.E., Wesemael, W.M.L. and Perry, R.N. (2013). Review: Top 10 plant-parasitic nematodes in molecular plant pathology. Molecular Plant Pathology DOI: 10.1111/mpp.12057.

Kaplan, D.T., Vanderspool, M.C. and Opperman, C.H. (1997). Sequence tag site and host range assays demonstrate that Radopholus similis and $R$. citrophilus are not reproductively isolated. Journal of Nematology 29: 421429. 
Keane, P.J. (2012). Horizontal or generalized resistance to pathogens in plants. In: Cumagun, C.J. (ed.). Plant Pathology. InTech, Rijeka, Croatia, pp. 327-362.

Kella, A.M. and Bekhiet, M.A. (2011). Aerial nematode galls on camphor trees induced by the relationship between fergusobia nematode and fergusonina insect. Egyptian Journal of Agronematology 10(2):170-176.

Koenning, S.R., Overstreet, C., Noling, J.W., Donald, P.A., Becker, J.O. and Fortnum, B.A. (1999). Survey of crop losses in response to phytoparasitic nematodes in the united states for 1994. Journal of Nematology 31(4S): 587-618.

Kouassi, A.B., Kerlan, M.C., Sobczac, M., Dantec, J.P., Rouaux, C., Ellisseche, D. and Mugniery, D. (2005). Genetics and phenotypic characterization of the hypersensitive resistance of Solanum sparsipilum to Meloidogyne incognita. Nematology 7(2): 213-225.

Luc, M., Bridge, J. and Sikora, R.A. (2005). Reflections on nematology in subtropical and tropical agriculture. In: Luc, M., Sikora, R.A. and Bridge, J. (Eds). Plant Parasitic Nematodes in Sub-tropical and Tropical Agriculture. CAB International, Wallingford, UK, pp. 1-10.

McCarter, J.P. (2008). Molecular approaches toward resistance to plant-parasitic nematodes. In: Berg, R.H. and Taylor, C.G. (Eds). Cell Biology of Plant Nematode Parasitism-Plant Cell Monographs. Springer-Verlag Press, Berlin, Germany, pp. 239-267.

McDonald, A.H. and Nicol, J.M. (2005). Nematode parasites of cereals. In: Luc, M., Sikora, R.A. and Bridge, J. (Eds). Plant Parasitic Nematodes in Sub-tropical and Tropical Agriculture. CAB International, Wallingford, UK, pp. 131-191.

McSorley, R., Arnett, J.D., Bost, S.C., Carter, W.W., Hafez, S., Johnson, A.W., Kirkpatrick, T., Nyczepir, A.P., Radewald, J.D., Robinson, A.F. and Schmitt, D.P. (1987). Bibliography of estimated crop losses in the United States due to plant parasitic nematodes. Annals of Applied Nematology 1: 6-12.

Molinari, S. (2011). Natural genetic and induced plant resistance, as a control strategy to plant-parasitic nematodes alternative to pesticides. Plant Cell Reports 30: 311-323.

Molinari, S. (2012). Resistance and virulence in plant-nematode interactions. In: Boeri, F. and Chung, J.A. (eds). Nematodes. Nova Science Publisher, Inc., New York, USA, pp. 59-82.

Neilson, R. and Boag, B. (1996). The predicted impact of possible climatic change on virus-vector nematodes in Great Britain. European Journal of Plant Pathology 102:193-99. 
Nicol, J.M. (2002). Important nematode pests. In: Curtis, B.C., Rajaram, S. and Gómez, M. (eds). Bread wheat improvement and production. FAO Plant Production and Protection Series 2002, p 567.

Nicol, J.M., Turner, S.J., Coyne, D.L., den Nijs, L., Hockland, S. and Tahna Maafi, Z. (2011). Current nematode threats to world agriculture. In: Jones, J., Gheysen, G. and Fenoll, C. (Eds) Genomics and molecular genetics of plant-nematode interactions. Springer, Dordrecht, The Netherlands, pp. 2143.

Noling, J.W. (1987). Partitioning crop losses. In: Veech, J.A. and Dickson, D.W. (Eds). Vistas on nematology. Hyattsville, MD: Society of Nematologists, pp. 64-74.

OEPP/EPPO (2009a). EPPO standards PM7/4(2) diagnostics. Bursaphelenchus xylophilus. Bull OEPP/EPPO Bull 39:344-353.

OEPP/EPPO (2009b). EPPO standards PM7/40(2) diagnostics. Globodera rostochiensis and G. pallida. Bull OEPP/EPPO Bull 39:354-368.

OEPP/EPPO (2009c). EPPO standards PM7/41(2) diagnostics. Meloidogyne chitwoodi and Meloidogyne fallax. Bull OEPP/EPPO Bull 39:5-17.

OEPP/EPPO (2009d). EPPO standards PM7/95(1) diagnostics. Xiphinema americanum sensu lato. Bull OEPP/EPPO Bull 39:382-392.

Salama, H.S. and Abd-Elgawad, M.M.M. (2003). Quarantine problems: an analytical approach with special reference to palm weevils and phytonematodes. Archives of Phytopathology and Plant Protection 36, 4146.

Sasser, J.N. (1988). A perspective on nematode problems worldwide. In: Saxena, M.C., Sikora, R.A. and Srivastava, J.P. (Eds) Proceedings of a workshop held at Larnaca, Cyprus, 1-5 March, 1987. ICARDA, Aleppo, Syria. pp. 112.

Sasser, J.N. and Freckman, D.W. (1987). A world perspective on nematology: the role of the society. In: Veech, J.A. and Dickson, D.W. (Eds) Vistas on nematology. Society of Nematologists Inc., Hyattsville, Maryland, USA, pp. $7-14$.

Siddiqi, M.R. (2000). Tylenchida: Parasites of Plants and Insects, 2nd edn. CAB International, Wallingford, UK, pp. 336-380.

Sikora R.A., Bridge J. and Starr J.L. (2005). Management practices: an overview of integrated nematode management technologies. In: Luc M., Sikora R.A. and Bridge J. (Eds). Plant Parasitic Nematodes in Subtropical and Tropical Agriculture, 2nd edn. CAB International, Wallingford, UK, pp. 793-825.

Singh, S.K., Hodda, M. and Ash, G.J. (2013). Plant-parasitic nematodes of potential phytosanitary importance, their main hosts and reported yield losses. Bulletin OEPP/EPPO Bulletin 43 (2): 334-374. 
Starr, J.L. and Roberts, P.A. (2004). Resistance to plant-parasitic nematodes. In: Chen, Z.X., Chen, S.Y. and Dickson, D.W. (Eds). Nematology, Advances and Perspectives, Vol. 2.. CAB International, Wallingford, UK, pp. 879-907.

Starr, J.L., Cook, R., and Bridge, J. (2002). Plant resistance to parasitic nematodes. CAB International, Wallingford, UK.

Subbotin, S.A., Inserra, R.N., Marais, M., Mullin, P., Powers, T.O., Roberts, P.A., Van den Berg, E., Yeates, G.W. and Baldwin, J.G. (2011). Diversity and phylogenetic relationships within the spiral nematodes of Helicotylenchus Steiner, 1945 (Tylenchida: Hoplolaimidae) as inferred from analysis of the D2-D3 expansion segments of 28S rRNA gene sequences. Nematology 13: 333-345.

Tzortzakakis, E.A., Adam, M.A.M., Blok, V.C., Paraskevopoulos, C. and Bourtzis, K. (2005). Occurrence of resistance-breaking populations of rootknot nematodes on tomato in Greece. European Journal of Plant Pathology 113:101-105.

Valette, C., Mounport, O., Nicole, M., arah, J.-L. and Baujard, P. (1998). Scanning electron mieroscopy study of two African populalions of Radopholus similis (Nematoda: Pratylenchidae) and proposal of $R$. citrophilus as junior synonym of $R$. similis. Fundamental and Applied Nematology 21: 139-146.

Vovlas, N., Troccoli, A., Palomares-Rius, J.E., De Luca, F., Liébanas, G., Landa, B.B. et al. (2011). Ditylenchus gigas n. sp. parasitizing broad bean: a new stem nematode singled out from the Ditylenchus dipsaci species complex using a polyphasic approach with molecular phylogeny. Plant Pathology 60: 762-775.

Wittwer, S.H. (1981). The 20 crops that stand between man and starvation. Farm Chemicals 144: 17-28. 


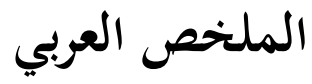

الفقد المحصولي بنيماتودا النبات: التحديات والفرص مع إشارة خاصة إلى مصر محفوظ محمد مصطفى عبد الجواد

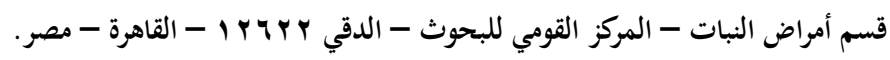

تشكل النيماتودا المتطفلة على النبات عائقا رئيسا للزراعة. يعتبر تقدير الخسائر التي تسببها

لكل محصول ذات أهمية في توجيه البحوث والإرشاد الزراعي، ووضع الأولوية في ميزانية إدارته.

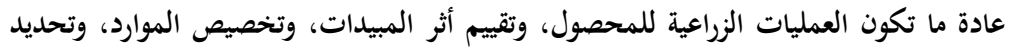

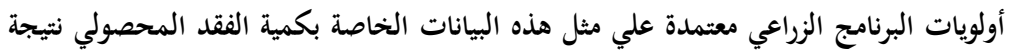

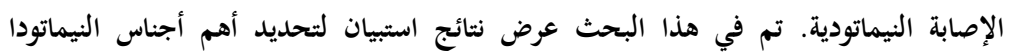
المتطفلة على النبات وتقدير الخسائر الناتجة عنها في ثمانين محصولاً في مصر منها

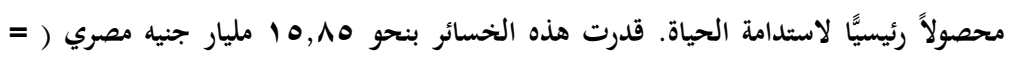
•

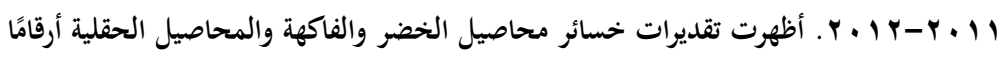

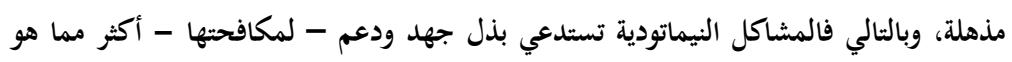

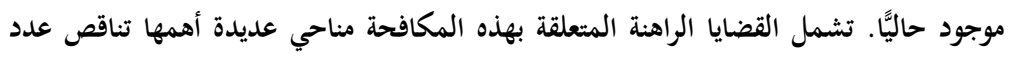

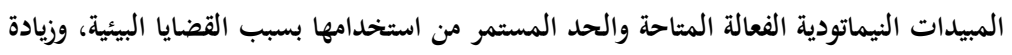

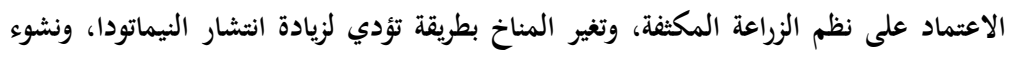
سلالات نيماتودية قادرة على كسر مقاومة الأصناف النباتية ذات الأهمية الاقتصادية، واحتمال

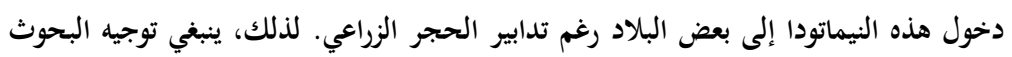
الأساسية والتطبيقية في مجال نيماتودا النبات لتوفير قدر أكبر من الفائدة الاقتصادية والبيئية. 